\title{
Enhanced stability of symmetrical polymer electrolyte membrane fuel cell single cells based on novel hierarchical microporous-mesoporous carbon supports
}

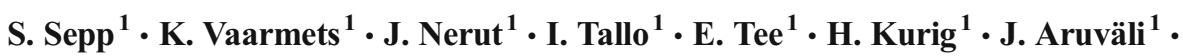 \\ R. Kanarbik ${ }^{1}$ - E. Lust ${ }^{1}$
}

Received: 5 September 2016 /Revised: 19 October 2016 / Accepted: 24 October 2016 / Published online: 10 November 2016

(C) The Author(s) 2016. This article is published with open access at Springerlink.com

\begin{abstract}
Fuel cell electrodes were prepared from $\mathrm{Pt}$ nanocluster activated hierarchical microporous-mesoporous carbon powders. The carbon supports were synthesized from molybdenum carbide applying the high-temperature chlorination method. Six different synthesis temperatures within the range from 600 to $1000{ }^{\circ} \mathrm{C}$ were used for preparation of carbon supports. Thermogravimetric analysis, X-ray diffraction, low-temperature nitrogen sorption, and high-resolution scanning electron microscopy methods were used to characterize the structure of the electrode materials and symmetrical membrane electrode assemblies (MEAs). The MEAs prepared were used to conduct the proton exchange membrane fuel cell (PEMFC)single-cell measurements. The polarization and power density curves for single cells were calculated to evaluate the activity of the catalyst materials synthesized. The electrochemically active surface area (from 2.4 to $11.9 \mathrm{~m}^{2} \mathrm{~g}^{-1}$ ) was obtained in order to estimate the contact surface areas of platinum and Nafion ${ }^{\circledR}$ electrolyte. The values of the electrolyte resistance, polarization resistance, and cell degradation rate were calculated from electrochemical impedance spectroscopy data. The carbon materials synthesized within temperature range from 600 to $850{ }^{\circ} \mathrm{C}$ were found to be the most suitable supports for PEMFCs, having higher maximum power density values and better stability (cell potential degradation $240 \mu \mathrm{V} \mathrm{h}^{-1}$ ) than commercial carbonbased (Vulcan XC72; $670 \mu \mathrm{V} \mathrm{h}^{-1}$ ) single cells.
\end{abstract}

E. Lust

enn.lust@ut.ee

1 Institute of Chemistry University of Tartu 14a Ravila Str, 50411 Tartu, Estonia
Keywords PEMFC cathode $\cdot$ Pt catalyst $\cdot$ Carbide-derived carbon support $\cdot$ Molybdenum carbide

\section{Introduction}

Proton exchange membrane fuel cell (PEMFC) is one of the most promising candidates as an environmentally clean power source for mobile and stationary applications. Due to relatively high efficiency, low operating temperature, quick start-up time, and the possibility to use bio and regenerative fuels (including hydrogen), PEMFC can be used as a power generation unit for automotive applications and in residential cogeneration systems [1-3]. PEMFC generates electric energy, water, and heat from the electrochemical reaction between hydrogen as a fuel and oxygen (from air) as an oxidant. The issues hindering the wide-scale commercialization of PEMFCs are high overpotential for oxygen electroreduction at/in the cathode and the decrease of the efficiency within long-term operation. Therefore, novel, more active, and durable materials are being sought for the PEMFC applications, especially for cathodes [4-7]. Improved catalysts could have a huge positive impact on the fuel cell efficiency and time stability.

Platinum is the most common catalyst material for PEMFC electrodes [1-7]. Apart from platinum, some other precious metal alloys with high stability have been investigated as possible catalysts in specially designed fuel cells $[8,9]$. Various precious metal-free electrocatalysts have also been studied, but the cyclability and time stability are the main problem, hindering the commercialization of these materials in various applications [10-13].

The efficiency of a catalyst depends strongly on the selection of an appropriate support material, including various modifications of carbon powders with different porosities 
and graphitization levels [14-19]. The demands for a support material are suitable porosity for quick mass transport, high electrical conductivity, and electrochemical stability (i.e., voltage cyclability) $[1-4,16-18,20]$. Various catalyst supports (Vulcan XC72, Ketjenblack EC-300, carbon nanotubes and nanofibers, some oxides, d-metal carbides, carbon-nitrogen d-metal complexes) have been studied and summarized by Antolini $[18,19]$. However, carbon materials, including porous carbon powders, are the most widely utilized supports due to suitable conductivity and porosity granting high dispersion of Pt nanoparticles $[1,7]$. The stability toward carbon oxidation/reduction process, known as carbon corrosion, is the major problem regarding their use in PEMFC application $[1,21,22]$. Other mechanisms like Pt dissolution and sintering as well as membrane thinning can reduce the useful life of a PEMFC. During operation, a PEMFC exhibits a gradual decline in power output as individual components are exposed to an aggressive combination of strong oxidizing conditions like low $\mathrm{pH}$, high temperature, high water content, and high electrochemical potential and oxygen concentration. Carbon corrosion to $\mathrm{CO}_{2}$ can be also enhanced by Pt catalysts, which may cause permanent loss of support material and even the collapse of the electrode [20,21].

Uchida et al. [14, 15], Chai et al. [16], and Antolini et al. $[18,19]$ have demonstrated that the properties of the carbon support have significant impact on the power output of PEMFC and the structure of the catalyst layer should be carefully optimized in order to achieve further improvement in the cathode performance. Under start-stop conditions, the corrosion of carbon support for conventional cathode catalysts is a critical problem for PEMFC durability in automotive applications [16-19, 23-25]. Therefore, different carbon supports [17-19, 23-31] have been tested during long-term catalyst optimization studies [16-19, 32-36]. Influence of structural parameters of PEMFC electrodes like the particle size, interparticle distance, and metal (Pt, Pt-metal, or non-Pt-metal) loading has been systematically tested and summarized in many papers [14-19, 21-28].

Carbon materials can be synthesized using various methods, e.g., high-temperature carbonization of carbon-rich organic precursors [19]. To prepare carbon materials with high specific surface area and well-defined hierarchical bimodal pore size distribution, the selective extraction of non-carbon elements from carbides can be used [24, 27-33, 35, 36]. Resulting carbide-derived carbons (CDCs) are unique microporous and mesoporous materials where pore size, pore shape, ratio of micropore area to mesopore area, ratio of micropore volume to mesopore volume, and other parameters (e.g., graphitization level) can be controlled in a very exact manner [24, 27-36]. It has been suggested that CDCs are viable fuel cell catalyst supports that are capable of realizing the full potential and electrochemical activity of Pt nanoparticles with superior corrosion stability [32-36].
In our previous paper [37], it was demonstrated that membrane electrode assemblies (MEAs) prepared from CDC carbon powder-based $\mathrm{Pt}-\mathrm{C}\left(\mathrm{Mo}_{2} \mathrm{C}\right)$ cathodes and $\mathrm{Pt}-\mathrm{C}($ Vulcan $\mathrm{XC72}$ ) anodes are excellent objects to study the impact of carbon catalyst support properties on the performance of a PEMFC single cell. The main aims of this work were to study the suitability of platinum nanocluster activated $\mathrm{Pt}-\mathrm{C}\left(\mathrm{Mo}_{2} \mathrm{C}\right)$ anodes and cathodes (i.e., MEAs with symmetrical chemical composition and structural characteristics) in the fuel cell single-cell conditions and to compare the properties of these materials with those for commonly used commercial carbon support Vulcan XC72-based catalyst Pt-C(Vulcan). In addition, comparison with data for asymmetrical $\mathrm{Pt}-\mathrm{C}\left(\mathrm{Mo}_{2} \mathrm{C}\right)$ |Nafion ${ }^{\circledR} 115$ |Pt-C(Vulcan) single cells will be given for demonstration of critical role of cathodes under study.

\section{Experimental}

\section{Preparation and deposition of Pt nanoclusters onto/into microporous-mesoporous carbon powders}

Approximately 1-g batches of different microporousmesoporous carbon powders were prepared using chlorination of $\mathrm{Mo}_{2} \mathrm{C}$ powders in the temperature range from 600 to $1000{ }^{\circ} \mathrm{C}$ as described in previous works $[30,31,35]$. The microporous-mesoporous products are hereafter noted as $\mathrm{C}\left(\mathrm{Mo}_{2} \mathrm{C}\right) 600{ }^{\circ} \mathrm{C}, \mathrm{C}\left(\mathrm{Mo}_{2} \mathrm{C}\right) 750{ }^{\circ} \mathrm{C}, \mathrm{C}\left(\mathrm{Mo}_{2} \mathrm{C}\right) 800{ }^{\circ} \mathrm{C}$, $\mathrm{C}\left(\mathrm{Mo}_{2} \mathrm{C}\right) 850{ }^{\circ} \mathrm{C}, \mathrm{C}\left(\mathrm{Mo}_{2} \mathrm{C}\right) 900{ }^{\circ} \mathrm{C}$, and $\mathrm{C}\left(\mathrm{Mo}_{2} \mathrm{C}\right) 1000{ }^{\circ} \mathrm{C}$. Synthesis temperatures were varied in order to prepare the materials with a very wide variation of specific surface area $\left(S_{\mathrm{BET}}\right)$ and microporosity-mesoporosity characteristics [30, 34].

The Pt nanoparticles were deposited onto the carbon support by the sodium borohydride reduction method $[35,37$, $38]$. For better comparison, the similar protocol with the previous works $[32,37]$ was used to synthesize about $0.4 \mathrm{~g}$ catalyst material (cathodes as well as anodes), where the mass percent of $\mathrm{Pt}$ in the catalyst materials synthesized was $\sim 70 \mathrm{wt} \%$ (14 at.\%, i.e., electrode loading was $\sim 0.7 \mathrm{mg}_{\mathrm{Pt}} \mathrm{cm}^{-2}$ ).

\section{Structural characterization}

The thermogravimetric analysis (TGA) in the atmosphere consisting of $80 \mathrm{vol} \% \mathrm{~N}_{2}$ and $20 \mathrm{vol} \% \mathrm{O}_{2}$ was carried out in order to estimate the content of Pt in the catalyst materials for cathodes and anodes using NETZSCH STA449F3. The temperature was varied from 40 to $1000{ }^{\circ} \mathrm{C}$ with a heating rate of $5^{\circ} \mathrm{C} / \mathrm{min}$ and with a gas flow rate of $120 \mathrm{~cm}^{3} \mathrm{~min}^{-1}$. Weight of the samples tested in the $\mathrm{Al}_{2} \mathrm{O}_{3}$ pan was $7-9 \mathrm{mg}$. According to the TGA measurement results, the platinum content was relatively same in all the materials studied: the average weight 
percentage of platinum in the anode and cathode samples was $71.8 \pm 1.7$ (Table 1$)$.

The X-ray diffraction (XRD) patterns for the materials were collected with a Bruker D8 Advance diffractometer with $\mathrm{Ni}$-filtered $\mathrm{Cu} K_{\alpha}$ radiation (0.6-mm-wide parallel beam, two $2.5^{\circ}$ Soller slits, and LynxEye line detector). The scanning step of $0.01^{\circ}$ for $2 \theta$ was applied from $16^{\circ}$ to $90^{\circ}$, and the total counting time per step was $166 \mathrm{~s}$.

The porosity of the powders was estimated using the lowtemperature $\left(-195.8^{\circ} \mathrm{C}\right)$ nitrogen sorption [38] method combined with $\mathrm{CO}_{2}$ sorption method [39] (Micromeritics ASAP 2020). The non-local density functional theory and the slit shape pore model $[38,39]$ were used for the pore size distribution calculation. The values of specific surface area, $S_{\mathrm{BET}}$, were calculated using the Brunauer-Emmett-Teller multipoint theory [38] within the relative pressure $\left(p / p_{0}\right)$ range from 0.05 to 0.2 . The total volume of pores (near saturation pressure), $V_{\text {tot }}$, and the volume of micropores, $V_{\text {micro }}$, were calculated using the $t$-plot method using the Harkins and Jura thicknesses between 0.5 and $0.9 \mathrm{~nm}$ [40]. The results of $\mathrm{N}_{2}$ sorption measurements are presented in Table 1. Deposition of the Pt nanoparticles onto Pt- $\mathrm{C}\left(\mathrm{Mo}_{2} \mathrm{C}\right)$ decreases the specific surface area of a catalyst, but the Pt nanocluster deposition does not change the shape of pore size distribution plot; i.e., the $\mathrm{Pt}-\mathrm{C}\left(\mathrm{Mo}_{2} \mathrm{C}\right)$ catalyst and $\mathrm{C}\left(\mathrm{Mo}_{2} \mathrm{C}\right)$ catalyst support have comparable macro-mesoporous structure and pore size distribution [33].

The high-resolution scanning electron microscopy (HRSEM) data were obtained using Helios ${ }^{\mathrm{TM}}$ Nanolab 600.

\section{Preparation of the membrane electrode assembly}

Catalyst ink for anode and cathode electrodes was prepared by suspending the Pt-C( $\left(\mathrm{Mo}_{2} \mathrm{C}\right)$ powder in the solution of Milli- $\mathrm{Q}^{+}$water, isopropanol (Sigma-Aldrich, >99\%), and Nafion ${ }^{\circledR}$ dispersion (Aldrich) in such ratio that the final dry catalyst layer would have $25 \mathrm{wt} \%$ content of Nafion ${ }^{\circledR}$ ionomer. Thereafter, the mixture was sonicated for $30 \mathrm{~min}$ to prepare uniformly dispersed ink, which was deposited onto the Nafion ${ }^{\circledR} 115$ membrane using spray gun and dried in a vacuum oven at $50 \mathrm{mbar}$ and $70^{\circ} \mathrm{C}$. MEAs with $5 \mathrm{~cm}^{2}$ electrodes were pressed before and after every coating procedure at $6 \mathrm{MPa}$ and $80{ }^{\circ} \mathrm{C}$ using isostatic laminator (Keko ILS-66) to achieve smooth surface of the electrodes.

The prepared MEA was placed between the graphite plates with septrine gas flow channels. The polytetrafluoroethylene gaskets $(0.25 \mathrm{~mm})$ and ELAT $1400 \mathrm{~W}$ gas diffusion layers [37] were used for assembling of the single cell. The single cell was held together by eight $6-\mathrm{mm}$ bolts with a torque of $5 \mathrm{~N} \mathrm{~m}$.

\section{Single-cell tests}

All electrochemical data were collected using a potentiostat/ galvanostat (PGSTAT302N with FRA32M, Autolab) connected to a booster (BOOSTER20A, Autolab). $\mathrm{H}_{2}$ and $\mathrm{O}_{2}$ with $100 \%$ relative humidity $(\mathrm{RH})$ were fed to the electrodes with fixed flow rates of $200 \mathrm{~cm}^{3} \mathrm{~min}^{-1}$ at atmospheric pressure. MKS-type M100B mass flow controllers were used. Fuel Cell Technologies dew point humidification system was used to regulate the gas flow rate and humidification level of gases.

Polarization curves were measured in the galvanostatic mode with 0.2-A intervals and 60-s data collection time for each point. Thereafter, the power density curves were calculated. The electrochemical impedance spectroscopy (EIS) measurements were performed in potentiostatic mode (cell potential $\Delta E=0.55 \mathrm{~V})$. A frequency range from 0.5 to $100,000 \mathrm{~Hz}$ with AC amplitude of $0.005 \mathrm{~V}$ (rms) was applied. The electrochemically active surface area (ECA) was calculated based on the traditional $\mathrm{H}_{2}$ adsorption method [40] based on the analysis of the current peaks (area of cyclic voltammograms peaks) of cyclic voltammetry curves measured within the potential range from 0.04 to $1.1 \mathrm{~V}$ at scan rates from 20 to $500 \mathrm{mV} \mathrm{s}^{-1}$ at $30^{\circ} \mathrm{C}$. Humidified (100\% RH) $\mathrm{N}_{2}$ was fed to
Table 1 Results of $\mathrm{N}_{2}$ sorption, TGA, and XRD measurements

\begin{tabular}{llllllll}
\hline Catalyst material & $\begin{array}{l}S_{\mathrm{BET}} \\
\left(\mathrm{m}^{2} \mathrm{~g}^{-1}\right)\end{array}$ & $\begin{array}{l}S_{\text {meso }} \\
\left(\mathrm{m}^{2} \mathrm{~g}^{-1}\right)\end{array}$ & $\begin{array}{l}V_{\text {tot }} \\
\left(\mathrm{cm}^{3} \mathrm{~g}^{-1}\right)\end{array}$ & $\begin{array}{l}V_{\text {meso }} \\
\left(\mathrm{cm}^{3} \mathrm{~g}^{-1}\right)\end{array}$ & $\begin{array}{l}\mathrm{wt} \% \\
(\mathrm{Pt})\end{array}$ & $a(\mathrm{~nm})$ & $\begin{array}{l}d \\
(\mathrm{~nm})\end{array}$ \\
\hline $\mathrm{Pt}-\mathrm{C}\left(\mathrm{Mo}_{2} \mathrm{C}\right) 600{ }^{\circ} \mathrm{C}$ & 510 & 110 & 0.43 & 0.22 & 74 & 0.3912 & 4.7 \\
$\mathrm{Pt}-\mathrm{C}\left(\mathrm{Mo}_{2} \mathrm{C}\right) 750{ }^{\circ} \mathrm{C}$ & 610 & 100 & 0.62 & 0.21 & 70 & 0.3912 & 4.1 \\
$\mathrm{Pt}-\mathrm{C}\left(\mathrm{Mo}_{2} \mathrm{C}\right) 800{ }^{\circ} \mathrm{C}$ & 550 & 200 & 0.64 & 0.41 & 70 & 0.3912 & 4.4 \\
$\mathrm{Pt}-\mathrm{C}\left(\mathrm{Mo}_{2} \mathrm{C}\right) 850{ }^{\circ} \mathrm{C}$ & 450 & 80 & 0.58 & 0.22 & 71 & 0.3913 & 4.1 \\
$\mathrm{Pt}-\mathrm{C}\left(\mathrm{Mo}_{2} \mathrm{C}\right) 900^{\circ} \mathrm{C}$ & 250 & 75 & 0.50 & 0.15 & 74 & 0.3914 & 3.8 \\
$\mathrm{Pt}-\mathrm{C}\left(\mathrm{Mo}_{2} \mathrm{C}\right) 1000^{\circ} \mathrm{C}$ & 220 & 60 & 0.42 & 0.12 & 73 & 0.3916 & 5.6 \\
$\mathrm{Pt}-\mathrm{C}(\mathrm{Vulcan})$ & 94 & 67 & 0.38 & 0.37 & 71 & 0.3914 & 4.6 \\
\hline
\end{tabular}

$S_{\mathrm{BET}}$ specific surface area, $S_{\text {meso }}$ mesopore area, $V_{\text {tot }}$ total pore volume, $V_{\text {meso }}$ mesopore volume, wt $\%$ weight percentage of platinum deposited onto/into the catalyst, $a$ lattice parameter of platinum, $d$ crystallite size of platinum calculated by Scherrer model ( $\mathrm{Pt}(220)$ reflection) 
the cathode and $\mathrm{H}_{2}$ to the anode with flow rates of 200 and $10 \mathrm{~cm}^{3} \mathrm{~min}^{-1}$, respectively.

\section{Results and discussion}

\section{Physical characterization of the Pt-C electrodes and MEAs}

SEM images of the MEAs prepared from Pt-C $\left(\mathrm{Mo}_{2} \mathrm{C}\right) 750^{\circ} \mathrm{C}$ and Pt-C(Vulcan) are shown in Fig. 1 (anode and cathode have been made from the same catalyst powder). Comparable data have been measured for all MEAs completed. The catalyst particles are clearly visible in Fig. 1a, b. Both catalyst layers have a good contact with the electrolyte layer. Differently from Pt-C(Vulcan), the $\mathrm{Pt}-\mathrm{C}\left(\mathrm{Mo}_{2} \mathrm{C}\right)$ electrode layer has non-homogenous structure, because the shape of the $\mathrm{C}\left(\mathrm{Mo}_{2} \mathrm{C}\right) 750{ }^{\circ} \mathrm{C}$ particles is irregular and the size varies from 1 to $4 \mu \mathrm{m}$. Data in Fig. $1 \mathrm{~b}$ show that there are large macropores between the $\mathrm{Pt}-\mathrm{C}\left(\mathrm{Mo}_{2} \mathrm{C}\right) 750^{\circ} \mathrm{C}$ particles which could facilitate the diffusion of reagents and simplify the water management. The particles of typical (traditional) PEMFC catalyst Pt-C(Vulcan) have a spherical shape with the average size about $0.1 \mu \mathrm{m}$. The macropores between the $\mathrm{Pt}-\mathrm{C}$ (Vulcan) particles are smaller being in the same order of magnitude $(0.1 \mu \mathrm{m})$. The platinum nanoparticles are evenly distributed across the surface of $\mathrm{C}\left(\mathrm{Mo}_{2} \mathrm{C}\right) 750{ }^{\circ} \mathrm{C}$ (Fig. 1c). Based on the particle size analysis of many surface areas (with more than 130 particles), the average size of the $\mathrm{Pt}$ nanoparticles deposited into/onto $\mathrm{C}\left(\mathrm{Mo}_{2} \mathrm{C}\right) 750{ }^{\circ} \mathrm{C}$ support was found to be $6.0 \pm 1.7 \mathrm{~nm}$ [37]. However, also somewhat bigger agglomerates of platinum nanoparticles have been deposited onto some surface areas (Fig. 1c). The size of non-agglomerated platinum nanoparticles is statistically reproducible and in a good agreement with the XRD data. The average crystallite size calculated from XRD data did not depend on the carbon material studied and was found to be $4.5 \pm 0.5 \mathrm{~nm}$ (Table 1). According to the analysis of the TGA and XRD data, the reproducibility of the catalyst material characteristics (Pt-loading and nanocluster structure) was good.

\section{Electrochemical characterization of the Pt-C-based single cells}

The polarization and power density curves

In Fig. 2, the polarization $(j, \Delta E)$ and power density $(j, P)$ curves for PEMFC single cells with different $\mathrm{Pt}-\mathrm{C}\left(\mathrm{Mo}_{2} \mathrm{C}\right)$ and Pt-C(Vulcan) electrodes are presented. At constant cell potential $(\Delta E=0.6 \mathrm{~V})$, the current density increases in the order of cathode materials: $\mathrm{Pt}-\mathrm{C}\left(\mathrm{Mo}_{2} \mathrm{C}\right) 1000{ }^{\circ} \mathrm{C}<\mathrm{Pt}$ $\mathrm{C}\left(\mathrm{Mo}_{2} \mathrm{C}\right) 900{ }^{\circ} \mathrm{C}<\mathrm{Pt}-\mathrm{C}($ Vulcan $)<\mathrm{Pt}-\mathrm{C}\left(\mathrm{Mo}_{2} \mathrm{C}\right) 800^{\circ} \mathrm{C} \approx \mathrm{Pt}-$ $\mathrm{C}\left(\mathrm{Mo}_{2} \mathrm{C}\right) 750{ }^{\circ} \mathrm{C}<\mathrm{Pt}-\mathrm{C}\left(\mathrm{Mo}_{2} \mathrm{C}\right) 600^{\circ} \mathrm{C}<\mathrm{Pt}-\mathrm{C}\left(\mathrm{Mo}_{2} \mathrm{C}\right) 850^{\circ} \mathrm{C}$. The maximal differences in power densities have been observed at very high current densities $\left(j>1 \mathrm{~A} \mathrm{~cm}^{-2}\right)$. The synthesized materials were used in symmetrical MEAs to evaluate the suitability of novel catalyst materials at both electrodes of the FC. It should be noted that comparable order of catalysts has been established for oxygen electroreduction (ORR) activity in the three-electrode system measured using different $\mathrm{CDCs}$ synthesized from $\mathrm{Mo}_{2} \mathrm{C}$ [33] as well as in nonsymmetrical single cells using $\mathrm{Pt}$ nanocluster activated Pt$\mathrm{C}\left(\mathrm{Mo}_{2} \mathrm{C}\right)$ as cathodes and Pt-C(Vulcan) as anodes [37]. Thus, the activity of symmetrical $\mathrm{Pt}-\mathrm{C}\left(\mathrm{Mo}_{2} \mathrm{C}\right)$ cathode and $\mathrm{Pt}-\mathrm{C}\left(\mathrm{Mo}_{2} \mathrm{C}\right)$ anode-based single cells is controlled by the electroreduction activity of the $\mathrm{O}_{2}$ on the cathode and the influence of the anode structural composition for $\mathrm{H}_{2}$ oxidation rate is negligible. Therefore, it can be concluded that all synthesized Pt-C $\left(\mathrm{Mo}_{2} \mathrm{C}\right)$ materials can be used as anodes and the $\mathrm{CDC}$ catalyst supports synthesized in the range from 600 to $850^{\circ} \mathrm{C}$ are performing well at the cathode.

Generally, the increase in the current and power densities of the cathode materials under study can be rationalized mainly with increase of the total pore volume of the cathode materials (Table 1). The symmetrical single cells based on $\mathrm{C}\left(\mathrm{Mo}_{2} \mathrm{C}\right)$
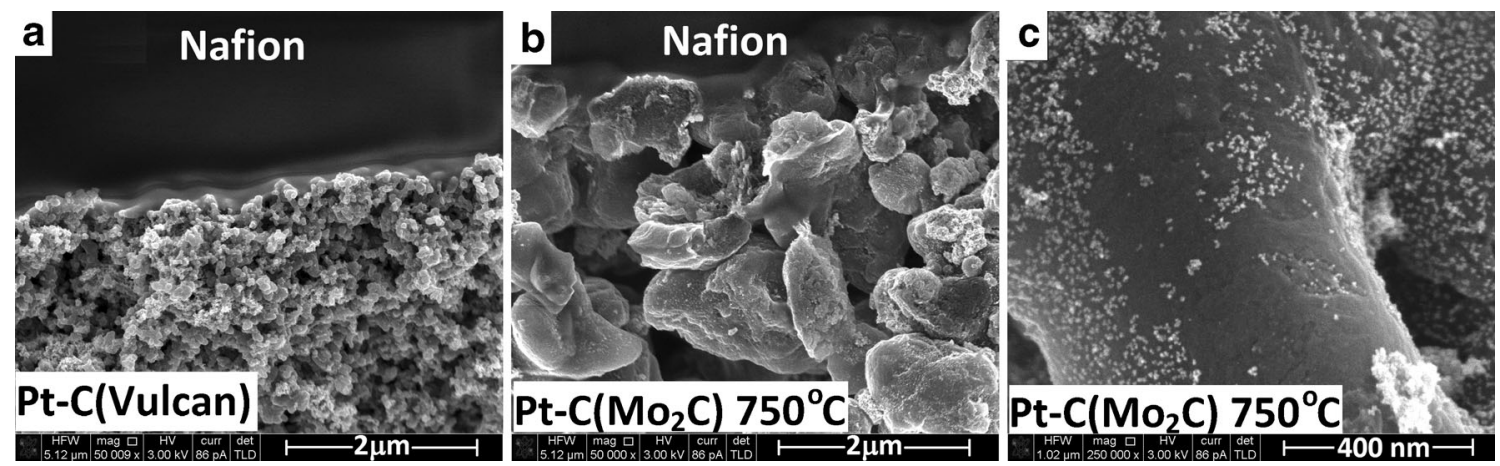

Fig. 1 The high-resolution scanning electron microscopy images of the membrane electrode assemblies $\left(\mathrm{Pt}-\mathrm{C}(\mathrm{Vulcan})\right.$ and $\mathrm{Pt}-\mathrm{C}\left(\mathrm{Mo}_{2} \mathrm{C}\right) 750{ }^{\circ} \mathrm{C}$, anode and cathode have been made using the same catalyst powder) 


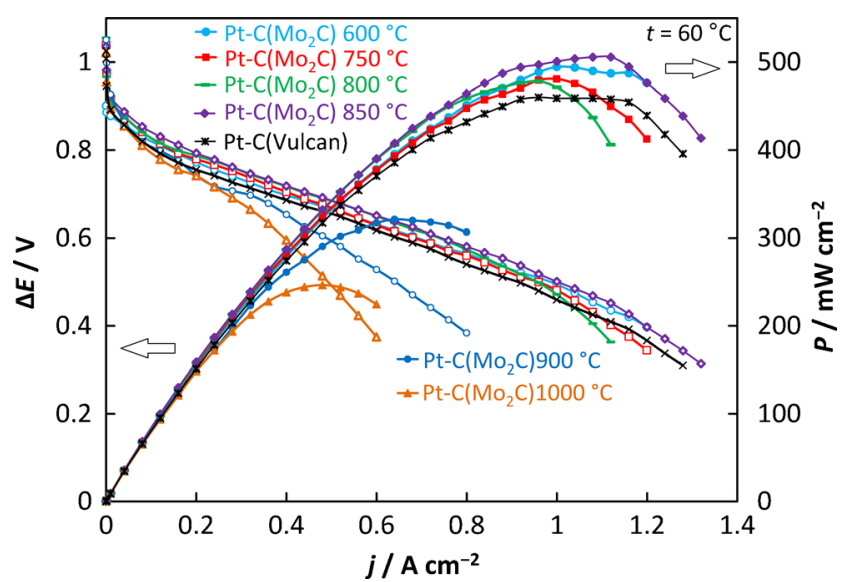

Fig. 2 The polarization and power density curves of the single cells with different electrode materials (noted in figure). Measurement conditions were as follows: $t=60{ }^{\circ} \mathrm{C}$ and atmospheric pressure; $100 \% \mathrm{RH}$ gases were fed to electrodes at flow rate $200 \mathrm{~cm}^{3} \mathrm{~min}^{-1}$

carbon powders that were synthesized at temperature in the range from 600 to $850^{\circ} \mathrm{C}$ demonstrated higher power values than Vulcan-based symmetrical single cell, which to the first approximation could be explained by higher total pore volume. However, single cells completed from Pt$\mathrm{C}\left(\mathrm{Mo}_{2} \mathrm{C}\right) 1000{ }^{\circ} \mathrm{C}$ and $\mathrm{Pt}-\mathrm{C}\left(\mathrm{Mo}_{2} \mathrm{C}\right) 900{ }^{\circ} \mathrm{C}$ with moderate total pore volume have much lower power values, which could be explained by relatively low specific surface area and mesopore volume values (data given in Table 1). It should be noted that the PEMFC symmetrical single cell completed from Pt-C(Vulcan) has intermediate activity (Table 2). Uchida et al. [14] found that the acetylene blacks as catalyst supports facilitate high activity of PEMFCs - the main reason mentioned was high amount of secondary pores (mainly mesopores and macropores according to IUPAC classification) within the porous electrode material (i.e., pores from 0.05 to $1.0 \mu \mathrm{m}$ [14]). Probably, the secondary pores in the mesoporous-macroporous surface of carbon support help to get good contact between gas phase, electrolyte, and $\mathrm{Pt}$ nanoparticle-based catalysts.
Within the region of maximum power density, the processes in the working single cell are mainly limited by the diffusion (mass transfer) step rate [42]. In this region, at $\Delta E=0.6 \ldots 0.9 \mathrm{~V}$, the current density values for Pt$\mathrm{C}\left(\mathrm{Mo}_{2} \mathrm{C}\right)$-based fuel cells are noticeably higher than that for the Pt-C(Vulcan)-based symmetrical system. Probably, these differences in the activity of the PEMFC single cells are caused by the enhanced oxygen mass transfer and ORR rate at the $\mathrm{Pt}-\mathrm{C}\left(\mathrm{Mo}_{2} \mathrm{C}\right) 600{ }^{\circ} \mathrm{C}, \mathrm{Pt}-\mathrm{C}\left(\mathrm{Mo}_{2} \mathrm{C}\right) 750{ }^{\circ} \mathrm{C}$, Pt$\mathrm{C}\left(\mathrm{Mo}_{2} \mathrm{C}\right) 800{ }^{\circ} \mathrm{C}$, and $\mathrm{Pt}-\mathrm{C}\left(\mathrm{Mo}_{2} \mathrm{C}\right) 850^{\circ} \mathrm{C}$ cathodes, explained also by the more effective water management of the $\mathrm{Pt}$ nanocluster activated materials under study.

In addition to high power density, long-lasting durability is very important for fuel cell catalysts, and therefore, the assembled single cells were tested in constant current regime $\left(j=0.4 \mathrm{~A} \mathrm{~cm}^{-2}\right.$ ) at $60{ }^{\circ} \mathrm{C}$ up to $600 \mathrm{~h}$ (Fig. 3). It should be noted that under these conditions and 160-h testing, the MEA prepared from Pt-C $\left(\mathrm{Mo}_{2} \mathrm{C}\right) 750{ }^{\circ} \mathrm{C}$ exhibited no severe cell potential drop $\left(\Delta E / \Delta t=240 \mu \mathrm{V} \mathrm{h}^{-1}\right)$. The MEA prepared form Pt-C(Vulcan) had much higher degradation rate $(\Delta E /$ $\Delta t=670 \mu \mathrm{V} \mathrm{h}^{-1}$ ) (Fig. 3), explained by lower electrochemical stability of the Vulcan $\mathrm{XC} 72$ support. The Pt-C $\left(\mathrm{Mo}_{2} \mathrm{C}\right) 750^{\circ} \mathrm{C}$ symmetrical single cells were tested longer applying the same conditions so that the total testing time at constant current was $600 \mathrm{~h}$. The potential drop between 160 and $600 \mathrm{~h}$ was $165 \mu \mathrm{V} \mathrm{h}^{-1}$ being slightly lower than the initial value $(\Delta E /$ $\Delta t=240 \mu \mathrm{V} \mathrm{h}^{-1}$ ).

The polarization and power density curves were measured before and after 160-h lifetime tests and are given in Fig. 4. Initial power density curves are fairly similar-the maximum power density was $480 \mathrm{~mW} \mathrm{~cm}{ }^{-2}$ for single cell based on $\mathrm{Pt}-\mathrm{C}\left(\mathrm{Mo}_{2} \mathrm{C}\right) 750{ }^{\circ} \mathrm{C}$ and $460 \mathrm{~mW} \mathrm{~cm}{ }^{-2}$ for Pt$\mathrm{C}$ (Vulcan)-based single cell. However, after the lifetime experiment $\left(160-\mathrm{h}\right.$ polarization at $0.4 \mathrm{~A} \mathrm{~cm}^{-2}$ at $\left.60^{\circ} \mathrm{C}\right)$, the difference was much more severe: single cell with Pt$\mathrm{C}\left(\mathrm{Mo}_{2} \mathrm{C}\right) 750{ }^{\circ} \mathrm{C}$ catalyst preserved high maximum power density up to $440 \mathrm{~mW} \mathrm{~cm}^{-2}$ (i.e., only $5 \%$ power drop), but the single cell with the Pt-C(Vulcan) catalysts retained only
Table 2 The single-cell characteristics for different symmetrical MEAs studied

\begin{tabular}{llllc}
\hline Catalyst material & OCP $(\mathrm{V})$ & $\Delta E$ at $0.001 \mathrm{~A} \mathrm{~cm}^{-2}(\mathrm{~V})$ & $P_{\max }\left(\mathrm{mW} \mathrm{cm}^{-2}\right)$ & $\mathrm{ECA}\left(\mathrm{m}^{2} \mathrm{~g}^{-1}\right)$ \\
\hline $\mathrm{Pt}-\mathrm{C}\left(\mathrm{Mo}_{2} \mathrm{C}\right) 600^{\circ} \mathrm{C}$ & 1.000 & 0.927 & 490 & 4.9 \\
$\mathrm{Pt}-\mathrm{C}\left(\mathrm{Mo}_{2} \mathrm{C}\right) 750^{\circ} \mathrm{C}$ & 1.035 & 0.971 & 480 & 10.9 \\
$\mathrm{Pt}-\mathrm{C}\left(\mathrm{Mo}_{2} \mathrm{C}\right) 800^{\circ} \mathrm{C}$ & 1.055 & 0.967 & 480 & 11.9 \\
$\mathrm{Pt}-\mathrm{C}\left(\mathrm{Mo}_{2} \mathrm{C}\right) 850^{\circ} \mathrm{C}$ & 1.036 & 0.982 & 500 & 9.4 \\
$\mathrm{Pt}-\mathrm{C}\left(\mathrm{Mo}_{2} \mathrm{C}\right) 900^{\circ} \mathrm{C}$ & 1.051 & 0.998 & 320 & 2.4 \\
$\mathrm{Pt}-\mathrm{C}\left(\mathrm{Mo}_{2} \mathrm{C}\right) 1000^{\circ} \mathrm{C}$ & 1.021 & 0.954 & 250 & 2.4 \\
Pt-C(Vulcan $)$ & 1.010 & 0.946 & 460 & 9.4 \\
\hline
\end{tabular}

$O C P$ open circuit potential, $E C A$ electrochemically active surface area, $\Delta E$ cell potential, $P_{\max }$ maximum power density 


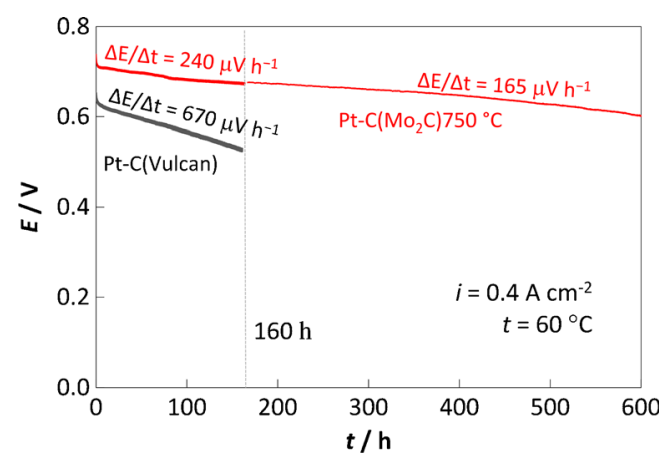

Fig. 3 Lifetime measurements of the symmetrical $\mathrm{Pt}-\mathrm{C}\left(\mathrm{Mo}_{2} \mathrm{C}\right) 750{ }^{\circ} \mathrm{C}$ and $\mathrm{Pt}-\mathrm{C}($ Vulcan) single cells (noted in figure) at constant current polarization regime $\left(j=0.4 \mathrm{~A} \mathrm{~cm}^{-2}\right)$ at $60{ }^{\circ} \mathrm{C}$. Measurement conditions: $t=60{ }^{\circ} \mathrm{C}$ and atmospheric pressure; $100 \% \mathrm{RH}$ gases were fed to electrodes at flow rate $50 \mathrm{~cm}^{3} \mathrm{~min}^{-1}$

$320 \mathrm{~mW} \mathrm{~cm}^{-2}$ (i.e., $30 \%$ power drop). Thus, the electrochemical conditions of the lifetime experiment caused much more damage to the MEA prepared from commercial carbon Vulcan XC72 as a catalyst support for both electrodes. The damage was probably mainly caused by carbon corrosion, growth of platinum particles, dissolution, and detachment of platinum particles from the carbon support. It must be noted that the open circuit potential (OCP) values did not change within durability tests, thus indicating that the decrease of power density is caused by degradation of the electrodes and not by development of the pinholes through Nafion ${ }^{\circledR}$ membrane. Further longer detailed studies (accelerated PEMFC single-cell tests) are under progress to confirm the low rate of $\mathrm{CDC}$ carbon oxidation/reduction under operating conditions at high positive potentials imitating the start-stop cycles of fuel cell [43].

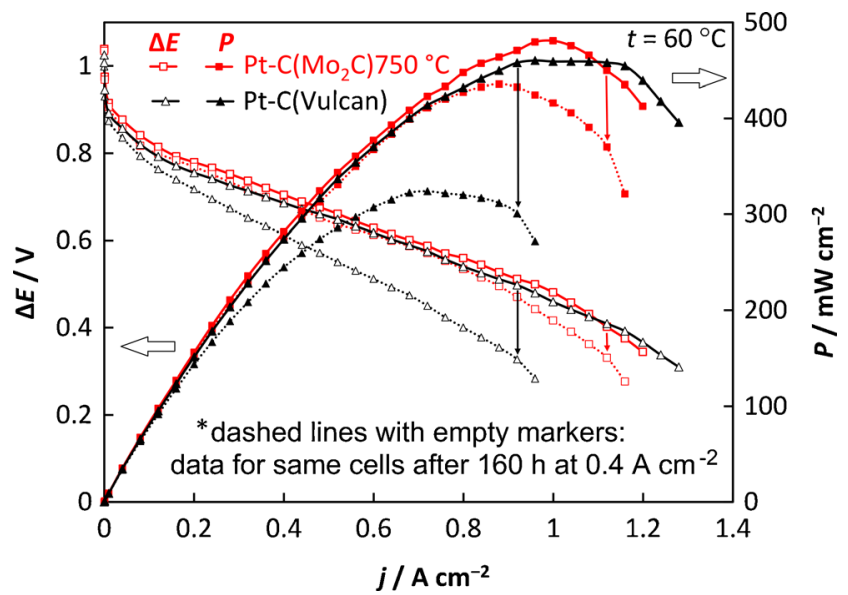

Fig. 4 The polarization and power density curves of the symmetrical Pt$\mathrm{C}\left(\mathrm{Mo}_{2} \mathrm{C}\right) 750{ }^{\circ} \mathrm{C}$ and Pt-C(Vulcan) single cells before and after the lifetime tests (noted in figure). Measurement conditions: $t=60{ }^{\circ} \mathrm{C}$ and atmospheric pressure; $100 \% \mathrm{RH}$ gases were fed to electrodes at flow rate $200 \mathrm{~cm}^{3} \min ^{-1}$

\section{The electrochemically active surface area}

To obtain further explanations of the reasons behind the very good activity and stability of the $\mathrm{Pt}-\mathrm{C}\left(\mathrm{Mo}_{2} \mathrm{C}\right) 750{ }^{\circ} \mathrm{C}$-based single cell, the oxygen gas was changed to nitrogen and the electrochemically active surface area (ECA) has been estimated at fixed temperature $\left(t=30^{\circ} \mathrm{C}\right)$. As seen in Fig. 5, there are very nice and clear current peaks in the cyclic voltammograms (CV) within the region of the formation and oxidation of hydrogen adatoms (from 0 to $0.3 \mathrm{~V}$ vs. reversible hydrogen electrode (RHE)). The values of capacitance $\left(C_{\mathrm{CV}}\right)$ have been calculated from current densities, $j$, using the equation $C_{\mathrm{CV}}=j / v[24,27-36]$. Very high $C_{\mathrm{CV}}$ values indicate that these single cells can be used as peak energy (supercapacitor like) generating devices [27-34] with increased lifetime and cyclability. Thereafter, the $C_{\mathrm{CV}}, E$-plots were integrated within the potential region of $H_{\text {ads }}$ formation and $H_{\text {ads }}$ re-oxidation [6, 41] in order to calculate charge values, $Q_{\mathrm{H}}$, for corresponding faradic reduction/oxidation processes applying the following equation:

$Q_{\mathrm{H}}=Q_{\mathrm{total}}-Q_{\mathrm{DL}}$

where $Q_{\text {total }}$ is the charge transferred within the proton reduction/hydrogen adsorption or desorption/ionization potential region and $Q_{\mathrm{DL}}$ is the charge inevitable for doublelayer formation, which has been estimated through a linear extrapolation of the current density value in the so-called double-layer region (approx. from 0.3 to $0.5 \mathrm{~V}$, Fig. 5). The ECA for platinum (in $\mathrm{m}^{2} \mathrm{~g}^{-1}$ ) was calculated (Table 2) with respect to the mass of platinum from the following formula:

$\mathrm{ECA}=\frac{Q_{\mathrm{H}}}{m_{\mathrm{Pt}} \cdot Q_{\mathrm{H}, \mathrm{ref}}}$

where $m_{\mathrm{Pt}}$ is the mass of $\mathrm{Pt}$ deposited onto/into the electrode (mg) and $Q_{\mathrm{H} \text {,ref. }}$ is the charge required to oxidize/reduce a monolayer of hydrogen adatoms on the compact polycrystalline (metallic) $\mathrm{Pt}$ (assumed as $0.21 \mathrm{mC} \mathrm{cm}^{-2}$ ) [41, 44]. Pt$\mathrm{C}\left(\mathrm{Mo}_{2} \mathrm{C}\right) 800{ }^{\circ} \mathrm{C}$ demonstrated the highest ECA value $\left(11.9 \mathrm{~m}^{2} \mathrm{~g}^{-1}\right)$, which is comparable with ECA values determined from our previous experiments [33], when this catalyst has been deposited onto the glassy carbon electrode and tested using the three-electrode configuration [33]. For other Pt$\mathrm{C}\left(\mathrm{Mo}_{2} \mathrm{C}\right)$ materials, the ECA values are slightly lower (Table 2), except for the $\mathrm{Pt}-\mathrm{C}\left(\mathrm{Mo}_{2} \mathrm{C}\right) 900{ }^{\circ} \mathrm{C}$ and $\mathrm{Pt}-$ $\mathrm{C}\left(\mathrm{Mo}_{2} \mathrm{C}\right) 1000{ }^{\circ} \mathrm{C}$ catalysts, demonstrating quite low ECA values. As the crystallite sizes of platinum for all materials prepared are only slightly variable (Table 2), the differences in the values of ECA and total activity of proton exchange membrane (PEM) single cells have been probably caused by the mass transport rate differences of $\mathrm{H}_{3} \mathrm{O}^{+}$and $\mathrm{O}_{2}$ into the 


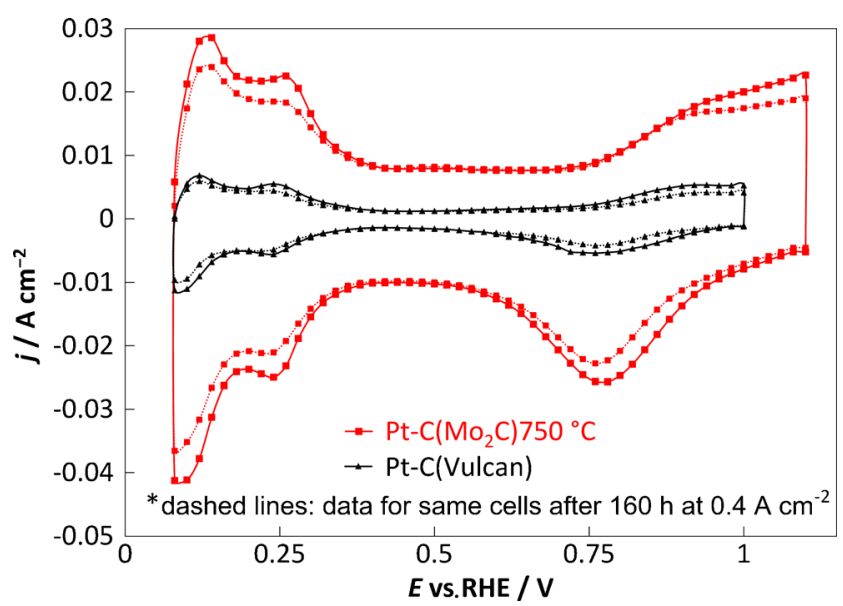

Fig. 5 The cyclic voltammograms for the symmetrical Pt$\mathrm{C}\left(\mathrm{Mo}_{2} \mathrm{C}\right) 750{ }^{\circ} \mathrm{C}$ and $\mathrm{Pt}-\mathrm{C}($ Vulcan $)$ single cells. Measurement conditions: $t=30{ }^{\circ} \mathrm{C}$, hydrogen flow rate $10 \mathrm{~cm}^{3} \mathrm{~min}^{-1}$ at the anode side, nitrogen flow rate $200 \mathrm{~cm}^{3} \mathrm{~min}^{-1}$ at the cathode side (both gases $100 \% \mathrm{RH})$, and scan rate $100 \mathrm{mV} \mathrm{s}^{-1}$

porous catalysts or by contact resistance of Nafion ${ }^{\circledR}$ with platinum nanoparticles at the Nafion ${ }^{\circledR}$ |platinum| carbon interface.

It should be noted that the calculated ECA values before the lifetime test were 10.9 and $9.4 \mathrm{~m}^{2} \mathrm{~g}^{-1}$ for $\mathrm{Pt}-\mathrm{C}\left(\mathrm{Mo}_{2} \mathrm{C}\right) 750{ }^{\circ} \mathrm{C}$ and Pt-C(Vulcan), respectively. The decrease of ECA value with 160-h lifetime is relatively similar for MEAs studied. The corresponding ECA values after lifetime test are $8.3 \mathrm{~m}^{2} \mathrm{~g}^{-1}$ for Pt-C $\left(\mathrm{Mo}_{2} \mathrm{C}\right) 750{ }^{\circ} \mathrm{C}$ and $7.3 \mathrm{~m}^{2} \mathrm{~g}^{-1}$ for Pt$\mathrm{C}$ (Vulcan). A more pronounced decrease of current density has been observed for Pt-C(Vulcan)-based single cells within the surface oxide formation/reduction region (from 0.6 to $1.0 \mathrm{~V}$ vs. RHE).

Thus, it can be concluded that the suitable properties of the carbon support (porosity, degree of graphitization, number of surface functional groups, etc.) are very important to achieve good electrical (and mechanical) contact between the catalyst particles and the proton conducting electrolyte. Therefore, the mentioned properties influence greatly the ECA and maximum power density values for PEMFC single cells, especially at high current densities $\left(j>1 \mathrm{~A} \mathrm{~cm}^{-2}\right)$.

\section{The electrochemical impedance characteristics}

Nyquist plots for all symmetrical single cells studied are presented in Fig. $6 \mathrm{a}(\Delta E=0.55 \mathrm{~V})$. As it can be seen, the pore size distribution of the catalyst materials has great influence on the total polarization resistance $\left(R_{\mathrm{p}}\right)$ values (difference between $Z$ ' values at frequency $f \rightarrow 0$ and $f \rightarrow \infty$ ) of the single cell. Thus, the controlled microporositymesoporosity has a noticeable effect on the kinetics of faradic reactions and the catalyst materials with higher mesopore volume (e.g., Pt-C $\left(\mathrm{Mo}_{2} \mathrm{C}\right) 800{ }^{\circ} \mathrm{C}$ and $\mathrm{Pt}$ -
$\left.\mathrm{C}\left(\mathrm{Mo}_{2} \mathrm{C}\right) 850^{\circ} \mathrm{C}\right)$ have much lower polarization resistances than the materials with lower mesopore volumes (e.g., Pt$\mathrm{C}\left(\mathrm{Mo}_{2} \mathrm{C}\right) 900{ }^{\circ} \mathrm{C}$ and $\left.\mathrm{Pt}-\mathrm{C}\left(\mathrm{Mo}_{2} \mathrm{C}\right) 1000{ }^{\circ} \mathrm{C}\right)$. Very high polarization resistance values for $\mathrm{Pt}-\mathrm{C}\left(\mathrm{Mo}_{2} \mathrm{C}\right) 1000{ }^{\circ} \mathrm{C}$-based PEMFC single cell can be explained also by the partial graphitization of the carbon support layers, thus by formation of the catalytically inactive (0001) basal planes and decreasing of the defect carbon surface areas, i.e., higher index carbon planes $(01 \overline{1} 0$, etc.) [45] as well as by decreasing the mass transport rate of oxygen in porous structure of the catalysts.

Nyquist plots in Fig. $6 \mathrm{~b}$ indicate that the high-frequency series resistance value and $R_{\mathrm{p}}$ for $\mathrm{Pt}-\mathrm{C}($ Vulcan$)$ and $\mathrm{Pt}$ $\mathrm{C}\left(\mathrm{Mo}_{2} \mathrm{C}\right) 750^{\circ} \mathrm{C}$ are nearly comparable before the lifetime tests. After the lifetime test, the $R_{\mathrm{p}}$ value increases only slightly for Pt-C $\left(\mathrm{Mo}_{2} \mathrm{C}\right) 750{ }^{\circ} \mathrm{C}$ (from 0.18 to $0.19 \Omega \mathrm{cm}^{-2}$, i.e., nearly $5 \%$ ), but the corresponding increase for Pt-C(Vulcan) is much more severe (from 0.18 to $0.31 \Omega \mathrm{cm}^{-2}$, nearly $70 \%$ ), which is in a good agreement with the CV data and with the decrease of power density data, discussed previously.

Thus, based on the analysis of the data collected, it can be summarized that the microporosity-mesoporosity (material
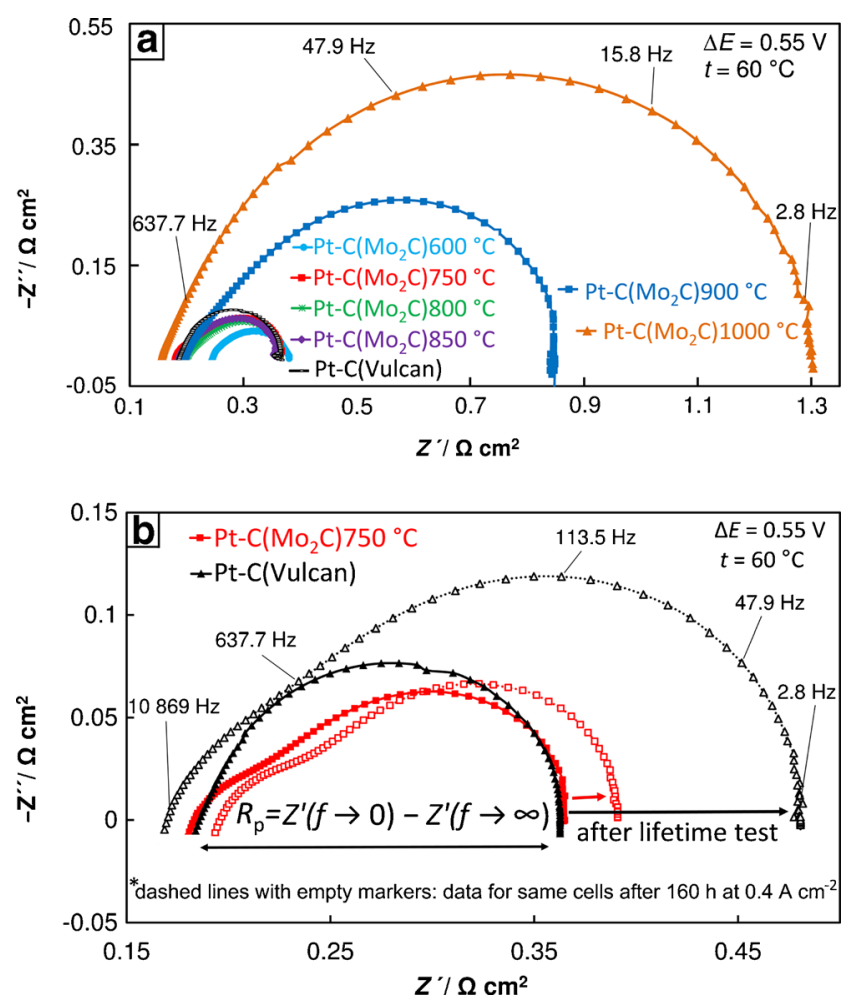

Fig. 6 Nyquist plots for the symmetrical single cells with different electrodes (noted in figure) (a) and for Pt-C $\left(\mathrm{Mo}_{2} \mathrm{C}\right) 750{ }^{\circ} \mathrm{C}$ and Pt$\mathrm{C}$ (Vulcan) before and after the lifetime experiment $(\mathbf{b})$ at cell potential $\Delta E=0.55 \mathrm{~V}$ and $60{ }^{\circ} \mathrm{C}$. Measurement conditions: $t=60{ }^{\circ} \mathrm{C}$ and atmospheric pressure; $100 \%$ RH gases were fed to electrodes at flow rate $200 \mathrm{~cm}^{3} \mathrm{~min}^{-1}$ 
mesopore volume) and the partial graphitization of the carbon support have noticeable effect on the ORR (and fuel oxidation) catalytic activity and electrochemical stability including cyclability of completed symmetrical single cells.

\section{Conclusions}

Symmetrical Pt-C $\left(\mathrm{Mo}_{2} \mathrm{C}\right)$ (same cathode and anode materials) fuel cell MEAs were prepared and tested in PEMFC single cells using various microporous-mesoporous carbide-derived carbon (CDC) catalyst supports. It was established that $\mathrm{CDCs}$ prepared from $\mathrm{Mo}_{2} \mathrm{C}$ at different temperatures from 600 to $1000{ }^{\circ} \mathrm{C}$ using the $\mathrm{Cl}_{2}$ treatment method can be successfully used as supports for Pt nanoparticles in the PEMFC applications. Physical properties of the carbon supports like crystal structure (crystallization level), specific surface area, and pore size distribution (micropore and mesopore volume) have great influence on the Pt$\mathrm{C}\left(\mathrm{Mo}_{2} \mathrm{C}\right)$-based PEMFC parameters, especially on the maximum power density at high current densities. It was shown that the high mesopore volume of the catalyst materials is a very important parameter due to the limitations of mass transport of $\mathrm{O}_{2}$ and $\mathrm{H}_{2} \mathrm{O}$ in the fuel cell working conditions. Comparison of the data with previous paper [37] indicates that the role of anode electrode material has very small influence on the single-cell characteristics (including power density) when pure $\mathrm{H}_{2}$ is used as a fuel. It was concluded that the temperature range from 600 to $850^{\circ} \mathrm{C}$ is optimal for $\mathrm{CDC}$ synthesis as the corresponding catalysts having suitable pore size distribution, microporositymesoporosity ratio, and MEAs prepared using these materials exhibited the highest power density values (for Pt$\mathrm{C}\left(\mathrm{Mo}_{2} \mathrm{C}\right) 850^{\circ} \mathrm{C} P=500 \mathrm{~mW} \mathrm{~cm}^{-2}$ at $t=60^{\circ} \mathrm{C}$, atmospheric pressure).

The results established for the Pt-C( $\left(\mathrm{Mo}_{2} \mathrm{C}\right)$-based electrodes were compared with those for commercial Vulcan XC72-based MEAs, and more than $10 \%$ increase in power density was achieved if $\mathrm{C}\left(\mathrm{Mo}_{2} \mathrm{C}\right) 850{ }^{\circ} \mathrm{C}$ has been used as the cathode and anode electrode supports for Pt nanocluster activated catalysts due to the higher specific surface area and more suitable pore size distribution. Time stability test during $600 \mathrm{~h}$ showed very low degradation for Pt- $\mathrm{C}\left(\mathrm{Mo}_{2} \mathrm{C}\right) 750{ }^{\circ} \mathrm{C}$ based symmetrical PEM single cell (cell potential drop $240 \mu \mathrm{V} \mathrm{h}^{-1}$ during $160 \mathrm{~h}$ and noticeably lower degradation rate of $160 \mu \mathrm{V} \mathrm{h}^{-1}$ from 160 to $600 \mathrm{~h}$ at $0.4 \mathrm{~A} \mathrm{~cm}^{-2}$ and $60{ }^{\circ} \mathrm{C}$ ). Therefore, longer time stability studies with the optimized structure of PEMFC electrodes will be carried on. Based on the information collected, it can be concluded that $\mathrm{CDCs}$ are promising catalyst support materials and $\mathrm{Pt}$ nanocluster activated CDCs can be used as the catalysts for PEMFC demonstrating high efficiency and good durability.
Acknowledgments This research was supported by the EU through the European Regional Development Fund (Centres of Excellence, 20142020.4.01.15-0011 and 3.2.0101-0030), Institutional Research Grant IUT20-13, and Personal Research Grants PUT55 and PUT1033.

Open Access This article is distributed under the terms of the Creative Commons Attribution 4.0 International License (http:// creativecommons.org/licenses/by/4.0/), which permits unrestricted use, distribution, and reproduction in any medium, provided you give appropriate credit to the original author(s) and the source, provide a link to the Creative Commons license, and indicate if changes were made.

\section{References}

1. Shahgaldi S, Hamelin J (2015) Improved carbon nanostructures as a novel catalyst support in the cathode side of PEMFC: a critical review. Carbon 94:705-728

2. Rohendi D, Majlan EH, Mohamad AB, Wan Daud WR, Hassan Kadhum AA, Shyuan LK (2013) Characterization of electrodes and performance tests on MEAs with varying platinum content and under various operational conditions. Int J Hydrog Energy 38: 9431-9437

3. Park Y-C, Kakinuma K, Uchida M, Uchida H, Watanabe M (2014) Deleterious effects of interim cyclic voltammetry on Pt/carbon black catalyst degradation during start-up/shutdown cycling evaluation. Electrochim Acta 123:84-92

4. Wang B (2005) Recent development of non-platinum catalysts for oxygen reduction reaction. J Power Sources 152:1-15

5. Petrii OA (2008) Pt-Ru electrocatalysts for fuel cells: a representative review. J Solid State Electrochem 12:609-642

6. Schmidt TJ, Gasteiger HA, Stäb GD, Urban PM, Kolb DM, Behm RJ (1998) Characterization of high-surface-area electrocatalysts using a rotating disk electrode configuration. J Electrochem Soc 145:2354-2358

7. Sepp S, Härk E, Valk P, Vaarmets K, Nerut J, Jäger R, Lust E (2014) Impact of the Pt catalyst on the oxygen electroreduction reaction kinetics on various carbon supports. J Solid State Electrochem 18: 1223-1229

8. Sasaki K, Mo Y, Wang JX, Balasubramanian M, Uribe F, McBreen J, Adzic RR (2003) Pt submonolayers on metal nanoparticlesnovel electrocatalysts for $\mathrm{H} 2$ oxidation and $\mathrm{O} 2$ reduction. Electrochim Acta 48:3841-3849

9. Corcoran CJ, Tavassol H, Rigsby MA, Bagus PS, Wieckowski A (2010) Application of XPS to study electrocatalysts for fuel cells. J Power Sources 195:7856-7879

10. Pylypenko S, Mukherjee S, Olson TS, Atanassov P (2008)Nonplatinum oxygen reduction electrocatalysts based on pyrolyzed transition metal macrocycles. Electrochim Acta 53:7875-7883

11. Serov A, Robson MH, Halevi B, Artyushkova K, Atanassov P (2012) Highly active and durable templated non-PGM cathode catalysts derived from iron and aminoantipyrine. Electrochem Commun 22:53-56

12. Tsivadze AY, Tarasevich MR, Andreev VN, Bogdanovskaya VA (2007) Prospects of low-temperature platinum-free fuel cells. Russ J Gen Chem 77:783-789

13. Bron M, Radnik J, Fieber-Erdmann M, Bogdanoff P, Fiechter S (2002) EXAFS, XPS and electrochemical studies on oxygen reduction catalysts obtained by heat treatment of iron phenanthroline complexes supported on high surface area carbon black. J Electroanal Chem 535:113-119

14. Uchida M, Fukuoka Y, Sugawara Y, Eda N, Ohta A (1996) Effects of microstructure of carbon support in the catalyst layer on the 
performance of polymer-electrolyte fuel cells. J Electrochem Soc 143:2245-2252

15. Uchida M, Park Y-C, Kakinuma K, Yano H, Tryk DA, Kamino T, Uchida H, Watanabe M (2013) Effect of the state of distribution of supported Pt nanoparticles on effective Pt utilization in polymer electrolyte fuel cells. Phys Chem Chem Phys 15:11236-11247

16. Chai GS, Yoon SB, Yu J-S, Choi J-H, Sung Y-E(2004) Ordered porous carbons with tunable pore sizes as catalyst supports in direct methanol fuel cell. J Phys Chem B 108:7074-7079

17. Zihrul P, Hartung I, Kirsch S, Huebner G, Hasché F, Gasteiger HA (2016) Voltage cycling induced losses in electrochemically active surface area and in H2/air-performance of PEM fuel cells. J Electrochem Soc 163:F492-F498

18. Antolini E (2016) Structural parameters of supported fuel cell catalysts: the effect of particle size, inter-particle distance and metal loading on catalytic activity and fuel cell performance. Appl Catal B Environ 181:298-313

19. Antolini E (2009) Carbon supports for low-temperature fuel cell catalysts. Appl Catal B Environ 88:1-24

20. Borup R, Meyers J, Pivovar B, Kim YS, Mukundan R, Garland N, Myers D, Wilson M, Garzon F, Wood D, Zelenay P, More K, Stroh K, Zawodzinski T, Boncella J, McGrath JE, Inaba M, Miyatake K, Hori M, Ota K, Ogumi Z, Miyata S, Nishikata A, Siroma Z, Uchimoto Y, Yasuda K, Kimijima K, Iwashita N (2007) Scientific aspects of polymer electrolyte fuel cell durability and degradation. Chem Rev 107:3904-3951

21. Roen LM, Paik CH, Jarvi TD (2004) Electrocatalytic corrosion of carbon support in PEMFC cathodes. Electrochem Solid-State Lett 7:A19-A22

22. Wickman B, Grönbeck H, Hanarp P, Kasemo B (2010) Corrosion induced degradation of $\mathrm{Pt} / \mathrm{C}$ model electrodes measured with electrochemical quartz crystal microbalance. J Electrochem Soc 157: B592-B598

23. Gottesfeld S, Raistrick ID, Srinivasan S (1987) Oxygen reduction kinetics on a platinum RDE coated with a recast Nafion film. J Electrochem Soc 134:1455-1462

24. Jänes A, Thomberg T, Lust E (2007) Synthesis and characterisation of nanoporous carbide-derived carbon by chlorination of vanadium carbide. Carbon 45:2717-2722

25. Du L, Shao Y, Sun J, Yin G, Liu J, Wang Y (2016) Advanced catalyst supports for PEM fuel cell cathodes. Nano Energy. doi:10.1016/j.nanoen.2016.03.016

26. Álvarez G, Alcaide F, Miguel O, Calvillo L, Lázaro M, Quintana J, Calderón J, Pastor E (2010) Technical electrodes catalyzed with $\mathrm{PtRu}$ on mesoporous ordered carbons for liquid direct methanol fuel cells. J Solid State Electrochem 14:1027-1034

27. Gogotsi Y, Nikitin A, Ye H, Zhou W, Fischer JE, Yi B, Foley HC, Barsoum MW (2003) Nanoporous carbide-derived carbon with tunable pore size. Nat Mater 2:591-594

28. Tallo I, Thomberg T, Jänes A, Lust E (2012) Electrochemical behavior of $\alpha$-tungsten carbide-derived carbon based electric doublelayer capacitors. J Electrochem Soc 159:A208-A213

29. Tallo I, Thomberg T, Kontturi K, Jänes A, Lust E (2011) Nanostructured carbide-derived carbon synthesized by chlorination of tungsten carbide. Carbon 49:4427-4433

30. Jänes A, Thomberg T, Kurig H, Lust E (2009) Nanoscale finetuning of porosity of carbide-derived carbon prepared from molybdenum carbide. Carbon 47:23-29

31. Thomberg T, Jänes A, Lust E (2009) Energy and power performance of vanadium carbide derived carbon electrode materials for supercapacitors. J Electroanal Chem 630:55-62. doi:10.1016/j. jelechem.2009.02.015

32. Lust E, Härk E, Nerut J, Vaarmets K (2013) Pt and Pt-Ru catalysts for polymer electrolyte fuel cells deposited onto carbide-derived carbon supports. Electrochim Acta 101:130-141

33. Lust E, Vaarmets K, Nerut J, Tallo I, Valk P, Sepp S, Härk E (2014) Influence of specific surface area and microporosity-mesoporosity of pristine and Pt-nanoclusters modified carbide derived carbon electrodes on the oxygen electroreduction. Electrochim Acta 140: 294-303

34. Borchardt L, Hasché F, Lohe MR, Oschatz M, Schmidt F, Kockrick E, Ziegler C, Lescouet T, Bachmatiuk A, Büchner B, Farrusseng D, Strasser P, Kaskel S (2012) Transition metal loaded silicon carbidederived carbons with enhanced catalytic properties. Carbon 50: $1861-1870$

35. Vaarmets K, Sepp S, Nerut J, Härk E, Tallo I, Lust E (2013) Electrochemical and physical characterization of Pt-Ru alloy catalyst deposited onto microporous-mesoporous carbon support derived from $\mathrm{Mo} 2 \mathrm{C}$ at $600{ }^{\circ} \mathrm{C}$. J Solid State Electrochem 17:1729 1741

36. Härk E, Nerut J, Vaarmets K, Tallo I, Kurig H, Eskusson J, Kontturi K, Lust E (2013) Electrochemical impedance characteristics and electroreduction of oxygen at tungsten carbide derived micromesoporous carbon electrodes. J Electroanal Chem 689: 176-184

37. Sepp S, Vaarmets K, Nerut J, Tallo I, Tee E, Kurig H, Aruväli J, Kanarbik R, Lust E (2016) Performance of polymer electrolyte membrane fuel cell single cells prepared using hierarchical microporous-mesoporous carbon supported Pt nanoparticles activated catalysts. Electrochim Acta 203:221-229

38. Ravikovitch PI, Neimark AV (2001) Characterization of nanoporous materials from adsorption and desorption isotherms. Colloids Surf Physicochem Eng Asp 187-188:11-21

39. Kurig H, Russina M, Tallo I, Siebenbürger M, Romann T, Lust E (2016) The suitability of infinite slit-shaped pore model to describe the pores in highly porous carbon materials. Carbon 100:617-624

40. Do DD (1998) Fundamentals of pure component adsorption equilibria. In: Adsorption analysis: equilibria and kinetics. Imperial College Press, London, p 11-48

41. Trasatti S, Petrii OA (1992) An international journal devoted to all aspects of electrode kinetics, interfacial structure, properties of electrolytes, colloid and biological electrochemistry real surface area measurements in electrochemistry. J Electroanal Chem 327:353376

42. Costamagna P, Srinivasan S (2001) Quantum jumps in the PEMFC science and technology from the 1960s to the year 2000: part II. Engineering, technology development and application aspects. J Power Sources 102:253-269

43. Petrone R, Hissel D, Péra MC, Chamagne D, Gouriveau R (2015) Accelerated stress test procedures for PEM fuel cells under actual load constraints: state-of-art and proposals. Int J Hydrog Energy 40: 12489-12505

44. Nores-Pondal FJ, Vilella IMJ, Troiani H, Granada M, de Miguel SR, Scelza OA, Corti HR (2009) Catalytic activity vs. size correlation in platinum catalysts of PEM fuel cells prepared on carbon black by different methods. Int J Hydrog Energy 34:8193-8203

45. Gara M, Compton RG (2011) Activity of carbon electrodes towards oxygen reduction in acid: a comparative study. New J Chem 35: 2647-2652 